\title{
Impact of Procedural Justice on Organizational Commitment with Moderating Effect of Pay Satisfaction
}

\author{
Muhammad Arif Khattak ${ }^{1 *}$, Muzammal Ilyas Sindhu ${ }^{1}$, Aftab Haider ${ }^{1}$, Syeda Faiza Urooj ${ }^{2}$ \\ ${ }^{1}$ Bahria University, Islamabad, Pakistan \\ ${ }^{2}$ Federal Urdu University, Islamabad, Pakistan
}

\begin{abstract}
The current study explored the relationship between procedural justice and organizational commitment with the moderating role of pay satisfaction. Furthermore, it also aimed to identify the impact of pay satisfaction on organizational commitment. The study was conducted based on the data collected from 400 employees from the telecom sector. The results of study revealed positive and significant impact of procedural justice and pay satisfaction on organizational commitment. It was also found that procedural justice plays a positive and significant role in enhancing organizational commitment behavior. Finally, the findings further suggested that pay satisfaction positively moderates the relationship between procedural justice and organizational commitment. Implications and suggestions are discussed for future research.
\end{abstract}

\section{Introduction}

Becker (1960) focused on organizational commitment and calculative commitment as forms of commitment. Later on several other researchers focused their attention towards this topic. During the late 1970s, Mowday et al. (1979) introduced another form of commitment and named that as attitudinal commitment. During 1990s, researchers focused heavily on organizational commitment. Meyer and Allen (1991) introduced three components model using three scales named as affective commitment scale (ACS), continuance commitment scale (CCS) and normative commitment scale (NCS).

Concept of procedural justice is derived from agency theory (Berle and Means, 1932; Simon, 1951); equity model (Adam, 1965) in which employee's perception about rewards and actual rewards they receive was explained. Leventhal et al. (1980) proposed six rules to determine procedural justice of the organization, which are, use of accurate data, input from employees, consistently apply decisions to all employees, no biased decision making, review questionable decisions and follow ethical standards. Agency theory also supported this concept, much like Property rights theorists (Voeller, 1987) claimed that when a transaction is conducted, a transaction cost occurs.

It was early 1960s when for the first time, researchers studied the relationship of Employee satisfaction with compensation by including the dimen-

*Corresponding author.

Email: arifkhattak78@gmail.com sion of pay in job descriptive index and Minnesota satisfaction questionnaire. Followed by focusing towards this dimension, but they used it as a generic term. In mid of 1970s, researchers used it specifically to include the dimension of satisfaction with pay, satisfaction with administration of compensation. Heneman III and Schwab (1985) defined four dimensions, which were satisfaction with pay level, benefits level, pay raises and structure/administration of compensation.

The aim of this study is twofold; one is to examine the impact of procedural justice and pay satisfaction on organizational commitment and second is to check the moderating effect of pay satisfaction in the relationship between procedural justice and organization commitment. The past researches studying the relationship between procedural justice and organization commitment haven't studied the relation with pay satisfaction. Organizational commitment has grabbed much attention in today's rapid changing and Global environment (Michaels, 1988).

Organizations want to attract and retain employees so that their effectiveness could be increased. Procedural Justice is very helpful for retaining employees in the organizations, such as when they perceive that different means used for making decisions are fair so they accept those decisions and stay loyal with the organization (Lind and Tyler, 1988). Pay Satisfaction has especially grabbed attention of many scholars, as literature supports the fact that pay satisfaction can stimulate trust and organizational commitment (Heneman 
and $L, 1992)$. Besides the presence of these kinds of theoretical arguments, there has been little empirical evidence present on the above-mentioned twofold study purpose, so it stimulated for further investigation on this relationship (Griffin et al., 2007).

A lot of researchers have found a direct relationship between pay satisfaction and several organizational outcomes like turnover intention, productivity, motivation and organizational commitment; and in congruence to meta-analytical review conducted by Judge and Colquitt (2004), this study is aimed to empirically test this theoretical relationship. between procedural justice and organization commitment by using pay satisfaction as a moderator.

Besides that, the current study endeavors to provide guidance to public sector for pay satisfaction and commitment. Native researchers will get support from these results and they can enhance this relation by including other variables like turnover intention. This research has the aim of providing non-discriminatory results regarding the moderating effect of pay satisfaction variable between other two variables procedural justice and organizational commitment.

\section{Literature Review}

\subsection{Procedural Justice and Organizational Commitment}

Cohen (1991) proposed that the relationship between organizational commitment and turnover varies across different stages of life and stated that procedural justice and communication of information is a very important predictor of turnover.

According to Cummings and Bromiley (1996) there are three dimensions of trust; honesty, avoiding excessive advantages relative to others and agreeing to depend on others. Scarpello and Vandenberg (1987) stated that satisfaction with supervisor means satisfaction with one's immediate boss, not with other conditions of the workplace or any kind of other agents. They further argued whether the employee who is satisfied with supervisor is also committed to the organization. It had been substabtiated that moral and alienate commitment is related to supervisor satisfaction while calculative commitment is not.

A study by Pfeffer (1994) investigated the relation of satisfaction with HR practices and the organization's commitment between three groups of employees; professional, line managers and workers. The results showed a significant relation between these variables. Pfeffer (1994) stated that best practices are HR practices, which can be implemented within any kind of organization, for any kind of employees and result in increased performance.

Hall and Schneider (1972) defined organizational commitment as employee's identification and attachment with organizational goals and values. Several researchers have attributed different concepts and explained the organizational commitment variable like loyalty, job involvement, job attachment, job commitment and moral commitment. Their results showed a positive effect of Organizational commitment towards desire to be part of organization and negatively related with turnover intention.

Smith and Peterson (1988) explained the three types of commitment as affective, continuance and normative. Gerhart and Rynes (2003) argued that different organizations are paying differently to its employees. Some are using individual performance criteria and some are focused on collective performance, i.e. team based; whereas some are using a hybrid approach. Several researchers have found a positive relation between incentives and performance and argued that when their performance increases, they are motivated and committed with organization, which ultimately reduces turnover rate.

Meyer and Allen (1991) claimed that due to socioeconomic changes and Globalization, importance of employee's attachment with organizations has increased and further argued that organizational commitment and organization support are two main dimensions, which form a bonding relationship between organization and employees.

Mowday et al. (2013) have discussed the attachment of employees with the organization and in explaining commitment, they said it is about employee's acceptance of values and goals, making efforts to achieve them and to remain part of the organization. Their findings showed the positive impact of affective commitment and perceived organizational support, whereas a negative relation between negative mood and perceived organizational support.

Chonko (1986) proposed that Organizational Commitment is independent and free from any kind of personal interests and temporary concerns. Mowday et al. (2013) defined it as a person's identification and desire to stay loyal and part of the organization. Their study investigated different aspects of organizational commitment and found that if employees are committed to their targets and goals of organizations, then it will lead to the organization's effectiveness. Age and income were un-correlated while anticipatory socialization, manager satisfaction and work satisfaction had positive relation with commitment; whereas job search behavior and perceived job alternatives were negatively related with organizational commitment.

Masterson et al. (2000) argued that organizational commitment is being predicted by procedural justice than Interactional justice as it is considered more accurate among these three types of organizational justice. Guth and MacMillan (1986) claimed that commitment with the organization is positively related to achieve- 
ment of organizational strategic goals. Mathieu and Zajac (1990) proposed that if management wants to increase satisfaction of its employees and reduce the absenteeism level, then it has to increase the commitment level of employees. Randall (1990) proposed that Organizational Commitment is a very important factor because it brings positive changes in employees and they exert more effort towards the achievement of organizational goals.

Citera and Rentsch (1993) proposed that organizational commitment to the managerial staff is dependent on three main factors: fairness of outcomes, fairness of the procedures and how their leaders treat them. Their study investigated the relation between organizational justice and managerial commitment. The findings suggested that procedural justice is positively related to affective commitment. Kramer and L (1996) also claimed that trust is an important variable and it plays a crucial role in Organizational Effectiveness, Efficiency and goal achievement.

Mitra et al. (1992) stated that turnover is studied with many variables because of its importance, as organizations wish to retain their employees, due to the high cost associated with the high turnover (advertisement, recruitment selection and training costs). Adams (1965) stated that fairness perception is very important for the employees because they not only compare benefits against their efforts as well as with their colleague;s benefits and efforts level. Folger and Konovsky (1989) claimed that Procedural Fairness brings a lot of benefits for the organization and most importantly results in job satisfaction, which ultimately leads to organizational commitment. Begley et al. (2006) proposed that a lot of attention is being given to organizational justice and argued about fair procedures by stating that if they are being used in the organization then employees accept the decisions.

Colquitt (2001) stated that this focus is due to one reason, which is the relationship of Procedural Justice with several organizational outcomes like Organizational Commitment, Job and Pay satisfaction, Absenteeism, etc. They investigated different factors of Procedural Justice. The findings showed a significant relation of Procedural Justice with effective performance of teams.

\subsection{Pay Satisfaction as a moderator}

Williams et al. (2006) proposed that employee's level of pay satisfaction is not only determined by absolute pay level, but it also depends on the relative comparisons and pay satisfaction is necessary for the organizations in order to make their compensation system successful. Cropanzano et al. (2002) investigated the relationship between contextual factors and Procedural Justice in promotion decisions for female employees. Their study results showed that individual cognitive processes develop a perception of Procedural Justice and also showed that Gender schema has significant contribution as a moderator between procedural justice and formal career path, as well as between procedural justice and perceived number of female employees as role models.

Milkovich et al. (2002) proposed that money is the basic incentive, which is used by managers to attract and retain employees. They argued that everyone sees money with a different eye. Cohen (1991) proposed that perception of fairness is necessary for the organizations, because they help to boost up employees and especially they are very much important for compensation related decisions. They claimed in previous research that when an organization is designing a pay system, it must focus on the fairness issue. Their research has been conducted to check the relationship between performance, gender and seniority with pay inequity, while studying how pay communication moderates this relationship. The results indicated that seniority and performance are related to perceived pay inequity while gender was not related and when pay system was communicated, employee satisfaction was enhanced.

\subsection{Hypotheses}

H1.There is a positive relationship between procedural justice and organizational commitment.

H2.There is a positive relationship between procedural justice and pay satisfaction.

H3.There is a positive relationship between pay satisfaction and organizational commitment.

H4.Pay satisfaction positively moderates the relation between procedural justice and organizational commitment.

\section{Theoretical Framework}

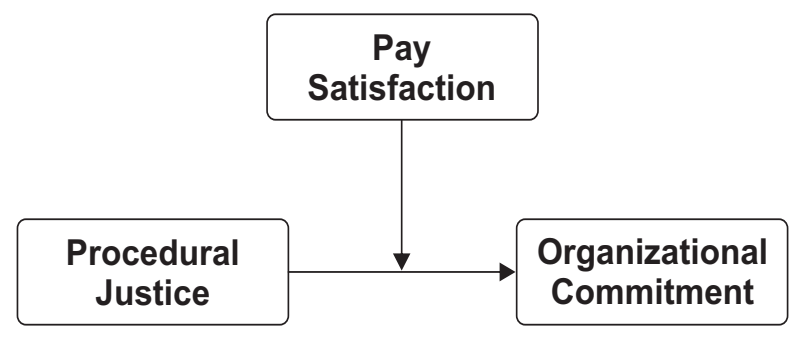

Figure 1: Theoretical framework. 


\section{Methodology}

This study is a deductive based approach in which hypothesis testing is elaborated using a sample of 242 respondents from telecom sectors. A purposive sampling technique is used for sample selection and response rate is $61 \%$. SPSS software is used to identify the relation between all three variables and reliability test, descriptive statistics, correlation matrix and regression analysis are considered sources for evaluation. Porter et al. (1974) scale is used for organizational commitment and its reliability value is 0.79 . Colquitt (2001) scale is utilized for testing procedural justice and its Cronbach's Alpha score is 0.71 which is satisfactory. Heneman III and Schwab (1985) scale is utilized for estimation of pay satisfaction with eighteen items and its reliability value is 0.88 .

\section{Results and Discussion}

The current study explored the influence of procedural justice on organizational commitment with the moderating impact of pay satisfaction. It is mandatory to confirm that data used in the study are normal before the start of correlation and regression analysis. Descriptive statistics are used for identification of mean, standard deviation, minimum and maximum of values and total number of items to scale considered for analysis. The results in descriptive statistics are showing that all the values are normally distributed and closure to neutral responses. Furthermore, standard deviation is showing the risk of each factor considered and Cronbach alpha is also mentioned here.

Table 1: Descriptive Statistics and Correlation Analysis

\begin{tabular}{lccccc}
\hline Variable & Mean & 1 & 2 & 3 & Alpha \\
\hline OC & 3.8 & 1 & & & 0.79 \\
PJ & 3.9 & $0.38^{* *}$ & 1 & & 0.71 \\
PS & 3.87 & $0.41^{* *}$ & $0.43^{* *}$ & 1 & 0.88 \\
\hline$* * p<0.01$ level of significance & & &
\end{tabular}

Table (1) shows reliability, descriptive statistics and correlation analysis of all three variables. The correlation between organizational commitment to procedural justice is positive and significant at 0.38 . The correlation between organizational commitment and pay satisfaction is significant at 0.41 , showing a direct positive significant relationship. Similarly, the correlation between procedural justice and pay satisfaction is significant at 0.43 , showing a direct positive significant relationship.

\subsection{Regression Analysis}

Regression analysis indicates the dependence of dependent variable upon independent variables. Organizational commitment was regressed on procedural justice to test the hypothesis. R-square indicates that how much variation in dependent variable comes from independent variable procedural justice.

Table (2) shows the results of regression analysis to find the effect of procedural justice on organizational commitment. The value of $R^{2}$ is 0.13 , which shows that procedural justice brings $13 \%$ change in organizational commitment. value of 0.379 shows that a significant change in organizational commitment is brought by procedural justice, which leads to the acceptance of hypothesis one.

Table 2: Regression analysis for Impact of Procedural Justice on Organizational Commitment

\begin{tabular}{lccc}
\hline Predictors & $\beta$ & $R^{2}$ & $\Delta R^{2}$ \\
\hline Step 1 & & & \\
Control Variables & & 0.13 & \\
Step 2 & & & \\
PJ & $0.379^{* *}$ & 0.13 & 0.14 \\
\hline${ }^{* *} p<0.01$ & & &
\end{tabular}

Table (3) shows the results of regression analysis to find the effect of procedural justice on pay satisfaction. The value of $R^{2}$ is 0.18 , which shows that procedural justice brings $18 \%$ change in pay satisfaction. $\beta$ value of 0.426 shows that a significant change in pay satisfaction is brought by procedural justice; henceforth, substantiating the acceptance of hypothesis two.

Table 3: Regression analysis for Impact of Procedural Justice on Pay Satisfaction

\begin{tabular}{lccc}
\hline Predictors & $\beta$ & $R^{2}$ & $\Delta R^{2}$ \\
\hline Step 1 & & & \\
Control Variables & & 0.18 & \\
Step 2 & & & \\
PJ & $0.426^{* *}$ & 0.18 & 0.17 \\
\hline${ }^{* *} p<0.01$ & & &
\end{tabular}

Table (4) shows regression analysis of 3 variables. The value of $R^{2}$ is 0.21 shows that $21 \%$ change was brought by adding pay satisfaction in the relationship, whereas, Beta weights are reduced from 0.36 
to 0.24 and it showed statistical significant results indicating moderation. The value of $\beta$ is 0.24 shows significant and positive impact of procedural justice on organizational commitment, while value $\beta$ is 0.29 shows significant and positive impact of pay satisfaction on organizational commitment; therefore, leading to the acceptance of hypothesis three. Moderation impact also showing significant and positive relationship, which means pay satisfaction significantly and positively moderates the relationship between procedural justice and organizational commitment. Thus, based on these results, hypothesis four has been accepted as well, i.e. pay satisfaction positively moderates the relationship between procedural justice and organizational commitment.

Table 4: Moderation Analysis

\begin{tabular}{lccc}
\hline \multicolumn{4}{c}{ Organizational Commitment } \\
\hline Predictors & $\beta$ & $R^{2}$ & $\Delta R^{2}$ \\
\hline Step 1 & & & \\
Control & & 0.21 & \\
Variables & & & \\
Step 2 & & & 0.24 \\
PJ & $0.240^{*}$ & 0.21 & \\
PS & $0.290^{*}$ & & \\
Step 3 & & & 0.19 \\
PJ x PS & $0.360^{*}$ & 0.18 & \\
\hline$* * p<0.01$ & & &
\end{tabular}

\section{Discussion}

This current study investigated the impact of procedural justice and pay satisfaction on organizational commitment and to investigate the moderating effect of pay satisfaction in fostering relation of procedural justice with organizational commitment. The first hypothesis anticipated a positive effect of procedural justice on organizational commitment and the proposition has been demonstrated valid as it is having a huge positive effect on organization commitment. Past inquires have displayed this effect as positive and this study is in accordance with them.

Second hypothesis anticipated positive impact of pay satisfaction on organizational commitment and results have substantiated this speculation by giving positive and critical qualities. Salaries are continually engaging element for workers as it is utilized to satisfy needs. Fulfillment with pay is the predecessor of hierarchical duty. The consequences of this study were again in accordance with past studies as Currall et al. (2005) led an exploration to discover the connection of pay satisfaction with organizational outcomes, where outcomes have demonstrated positive relationship between pay satisfaction measurements and unwavering quality estimation of $84 \%$. The third hypothesis anticipated impact of procedural justice and pay satisfaction and results have substantiated the hypothesis. Till and Karren (2011) directed study to check the effect of association equity on pay level satisfaction. Outcomes have demonstrated noteworthy and positive effect. Stone et al. (2010) directed study to check fairness perception and satisfaction with segments of pay satisfaction, where outcomes demonstrated positive effect.

Fourth hypothesis anticipated pay satisfaction as moderator with procedural justice and organization commitment. Results indicated that pay satisfaction positively moderates the relationship between procedural justice and organizational commitment. Couple of past studies have taken pay satisfaction as a go between organization effectiveness and job satisfaction.

\section{Conclusion}

The finishing up comments after the whole examination and talk, we have thought of descriptive statistics, correlation, regression, analysis of procedural justice, pay satisfaction and the organization's commitment. It demonstrates the positive effect of procedural justice and pay satisfaction on organizational commitment and positive moderation by including pay satisfaction between procedural justice and organizational commitment. These factors are noteworthy and decisions related with each other. Regression analysis is quite significant, and reliability values of organizational commitment, procedural justice and pay satisfaction are also above benchmark respectively, consequently leading to the acceptance of all four hypotheses.

Existence of procedural justice in any organization indicates that workers are happy with their compensation, then their dedication level with the organization builds which is a decent sign for general organizational performance. This research could be replicated in other economies with the addition of other variables and increasing number of samples. Furthermore, pay structure must be designed on fairness parameters so that each employee should have the perception of fairness and equity in mind and show more efforts towards achievement in financial and non-financial objectives of the organization.

Managers and supervisors should develop a conducive organizational internal environment in acquiring reasonableness all strategies utilized for making decisions. The organization should design remuneration structure in such a way where employees are mo- 
tivated to put effort in return of rewards. Managers should provide training opportunities regarding fairness issues so that all employees follow ethical guidelines and overtake organizational goals, so that they become loyal with organization and remove conflicts.

\section{References}

Adam, H. (1965). Adenosine-5'-diphosphate and adenosine5'-monophosphate. In Methods of enzymatic analysis, pages 573-577. Academic Press New York.

Becker, H. S. (1960). Notes on the concept of commitment. American Journal of Sociology, 66(1):32-40.

Begley, T. M., Lee, C., and Hui, C. (2006). Organizational level as a moderator of the relationship between justice perceptions and work-related reactions. Journal of Organizational Behavior, 27(6):705-721.

Berle, A. and Means, G. (1932). The modern corporate and private property. McMillian, New York, NY.

Chonko, L. B. (1986). Organizational commitment in the sales force. Journal of Personal Selling $\mathcal{E}$ Sales Management, 6(3):19-28.

Citera, M. and Rentsch, J. R. (1993). Is there justice in organizational acquisitions? the role of distributive and procedural fairness in corporate acquisitions.

Cohen, A. (1991). Career stage as a moderator of the relationships between organizational commitment and its outcomes: A meta-analysis. Journal of Occupational Psychology, 64(3):253-268.

Colquitt, J. A. (2001). On the dimensionality of organizational justice: a construct validation of a measure. Journal of applied psychology, 86(3):386.

Cropanzano, R., Prehar, C. A., and Chen, P. Y. (2002). Using social exchange theory to distinguish procedural from interactional justice. Group $\mathcal{E}$ Organization Management, 27(3):324-351.

Cummings, L. L. and Bromiley, P. (1996). The organizational trust inventory (oti). Trust in organizations: Frontiers of theory and research, 302(330):39-52.

Currall, S. C., Towler, A. J., Judge, T. A., and Kohn, L. (2005). Pay satisfaction and organizational outcomes. Personnel psychology, 58(3):613-640.

Folger, R. and Konovsky, M. A. (1989). Effects of procedural and distributive justice on reactions to pay raise decisions. Academy of Management journal, 32(1):115-130.

Gerhart, B. and Rynes, S. (2003). Compensation: Theory, evidence, and strategic implications. SAGE publications.

Griffin, M. A., Neal, A., and Parker, S. K. (2007). A new model of work role performance: Positive behavior in uncertain and interdependent contexts. Academy of management journal, 50(2):327-347.
Guth, W. D. and MacMillan, I. C. (1986). Strategy implementation versus middle management self-interest. Strategic Management Journal, 7(4):313-327.

Hall, D. T. and Schneider, B. (1972). Correlates of organizational identification as a function of career pattern and organizational type. In Academy of Management Proceedings, volume 1972, pages 159-161. Academy of Management.

Heneman and L, R. (1992). Merit pay: Linking pay increases to performance ratings. Addison-Wesley/Addison Wesley Longman.

Heneman III, H. G. and Schwab, D. P. (1985). Pay satisfaction: Its multidimensional nature and measurement. International journal of Psychology, 20(2):129-141.

Judge, T. A. and Colquitt, J. A. (2004). Organizational justice and stress: the mediating role of work-family conflict. Journal of Applied Psychology, 89(3):395.

Kramer and L, S. (1996). Geotechnical earthquake engineering. Pearson Education India.

Leventhal, G. S., Karuza, J., and Fry, W. R. (1980). Beyond fairness: A theory of allocation preferences. Justice and social interaction, 3(1):167-218.

Lind, E. A. and Tyler, T. R. (1988). The social psychology of procedural justice. Springer Science \& Business Media.

Masterson, S. S., Lewis, K., Goldman, B. M., and Taylor, M. S. (2000). Integrating justice and social exchange: The differing effects of fair procedures and treatment on work relationships. Academy of Management journal, 43(4):738-748.

Mathieu, J. E. and Zajac, D. M. (1990). A review and meta-analysis of the antecedents, correlates, and consequences of organizational commitment. Psychological bulletin, 108(2):171.

Meyer, J. P. and Allen, N. J. (1991). A three-component conceptualization of organizational commitment. Human resource management review, 1(1):61-89.

Michaels, C. F. (1988). Sr compatibility between response position and destination of apparent motion: evidence of the detection of affordances. Journal of Experimental Psychology: Human Perception and Performance, 14(2):231.

Milkovich, G. T., Newman, J. M., Milkovich, C., and Mirror, T. (2002). Compensation, volume 8. McGraw-Hill New York.

Mitra, A., Jenkins, G. D., and Gupta, N. (1992). A metaanalytic review of the relationship between absence and turnover.

Mowday, R. T., Porter, L. W., and Steers, R. M. (2013). Employee' organization linkages: The psychology of commitment, absenteeism, and turnover. Academic press.

Mowday, R. T., Steers, R. M., and Porter, L. W. (1979). The measurement of organizational commitment. Journal of vocational behavior, 14(2):224-247. 
Pfeffer, J. (1994). Competitive advantage through people: Unleashing the power of the work force. Harvard Business Press.

Porter, L. W., Steers, R. M., Mowday, R. T., and Boulian, P. V. (1974). Organizational commitment, job satisfaction, and turnover among psychiatric technicians. Journal of applied psychology, 59(5):603.

Randall, D. M. (1990). The consequences of organizational commitment: Methodological investigation. Journal of organizational Behavior, 11(5):361-378.

Scarpello, V. and Vandenberg, R. J. (1987). The satisfaction with my supervisor scale: Its utility for research and practical applications. Journal of Management, 13(3):447-466.

Simon, H. A. (1951). A formal theory of the employment relationship. Econometrica: Journal of the Econometric Society, pages 293-305.
Smith, P. B. and Peterson, M. F. (1988). Leadership, organizations and culture: An event management model. Sage Publications, Inc.

Stone, T. H., Jawahar, I., and Kisamore, J. L. (2010). Predicting academic misconduct intentions and behavior using the theory of planned behavior and personality. Basic and Applied Social Psychology, 32(1):35-45.

Till, R. E. and Karren, R. (2011). Organizational justice perceptions and pay level satisfaction. Journal of Managerial Psychology, 26(1):42-57.

Voeller, J. (1987). A note on fair equality of rules. In Agency Theory, Information, and Incentives, pages 473-480. Springer.

Williams, M. L., McDaniel, M. A., and Nguyen, N. T. (2006). A meta-analysis of the antecedents and consequences of pay level satisfaction. 